\title{
Genetic and genomic approaches for R-gene mediated disease resistance in tomato: retrospects and prospects
}

\author{
M. R. Ercolano $\cdot$ W. Sanseverino $\cdot$ P. Carli $\cdot$ \\ F. Ferriello $\cdot$ L. Frusciante
}

Received: 20 December 2011/Revised: 27 January 2012/ Accepted: 27 January 2012/Published online: 18 February 2012

(C) The Author(s) 2012. This article is published with open access at Springerlink.com

\begin{abstract}
Tomato (Solanum lycopersicum) is one of the world's most important vegetable crops. Managing the health of this crop can be particularly challenging; crop resistance may be overcome by new pathogen races while new pathogens have been introduced by global agricultural markets. Tomato is extensively used as a model plant for resistance studies and much has been attained through both genetic and biotechnological approaches. In this paper, we illustrate genomic methods currently employed to preserve resistant germplasm and to facilitate the study and transfer of resistance genes, and we describe the genomic organization of R-genes. Patterns of gene activation during disease resistance response, identified through functional approaches, are depicted. We also describe the opportunities offered by the use of new genomic technologies, including high-throughput DNA sequencing, large-scale expression data production and the comparative hybridization technique, whilst reporting multifaceted approaches to achieve genetic tomato disease control. Future strategies combining the huge amount of genomic and genetic data will be able to accelerate development of novel resistance varieties sustainably on a worldwide basis. Such strategies are discussed in the context of the latest insights obtained in this field.
\end{abstract}

Communicated by R. Reski.

M. R. Ercolano $(\bowtie) \cdot$ W. Sanseverino - P. Carli · F. Ferriello ·

L. Frusciante

Department of Soil, Plant, Environmental and Animal

Production Sciences, University of Naples 'Federico II',

Via Università 100, 80055 Portici, Italy

e-mail: ercolano@unina.it
Keywords Solanum lycopersicum - Disease resistance . Genomic tools $\cdot$ Emerging technologies $\cdot$ New breeding methods

\section{Introduction}

Tomato (Solanum lycopersicum) is one of most important vegetable crops worldwide. This species is susceptible to over 200 diseases caused by all types of pathogens, including viruses, bacteria, fungi and nematodes (Lukyanenko 1991). Chemical control is often too expensive for growers and in some cases ineffective. Moreover, the use of such chemicals has been reduced due to environmental and consumer constraints. Hence understanding the basis of tomato-pathogen interactions and the development of resistant cultivars are important research goals for achieving sustainable agriculture.

Tomato health management can be particularly challenging due both to resistance being overcome by new pathogen races and to the introduction of new pathogens by global agricultural markets. To date, the most important gene family involved in pathogen recognition analyzed in tomato has been that of resistance genes (R-genes). R-genes encode proteins that recognize avirulent (Avr) pathogen proteins and initiate the defence mechanisms culminating in a hypersensitive response (HR). Plant immune systems can also respond to an infection through sensitization of their basal immune system that shares elements with the R-gene mediated response (Postel and Kemmerling 2009). Most commercial cultivars possess $\mathrm{R}$-genes that confer resistance to fusarium wilt, verticillium wilt, root-knot nematode, alternaria stem canker, gray leaf spot, and some bacterial and viral diseases. For several tomato diseases such as early blight, powdery mildew, 
bacterial canker and bacterial wilt, horizontal resistance has been identified. For late blight and powdery mildew both vertical and horizontal resistances are available (Foolad 2007).

Tomato is extensively used as a model plant for resistance studies. Much has been achieved through the classical genetic approach (Ji et al. 2007). Current advances in plant biotechnology, including structural and functional genomics, can provide important tools for tomato improvement in developed and developing countries (Matsukura et al. 2008). During the last two decades, the use of molecular markers has facilitated identification, mapping and transfer of many disease resistance genes into tomato (Foolad 2007; Labate et al. 2007). A considerable number of studies have been undertaken to ascertain the molecular basis of resistance mechanisms underlying the defence process and plant-pathogen interactions. Numerous advances have been made in our knowledge of Verticillium dahliae, Fusarium oxysporum, Cladosporium fulvum, Pseudomonas syringae pv. tomato, tomato spotted wilt virus (TSWV), and tomato yellow leaf virus (TYLC) Meloidogyne spp. resistance processes, and steps toward the genetic control of these pathogens have also been taken (van Ooijen et al. 2007). In some areas where resistance genes or agronomic strategies are already used to control some serious diseases, others have emerged such as viruses (Hanssen et al. 2010) and Tuta absoluta, which can affect tomato crops (Desneux et al. 2010). It is therefore very important to implement a multifaceted approach toward disease control that is based both on a comprehensive knowledge of host-pathogen interactions and on a connected genomic strategy. In this way isolation of new tomato R-genes and their transfer through breeding approaches can bring many benefits in terms of ecology, economics and health for a growing sustainable agriculture.

This paper reports an overview of different biotechnology approaches available for improving tomato disease resistance. Methods employed to preserve resistant germplasm and explore structural genomic features are illustrated. We report recent advances to elucidate the role and mechanism of action of genes involved in the tomato defence response process. Opportunities offered by emerging technologies are discussed in the context of the latest insights obtained in this field. Future strategies that combine the huge amount of genetic and genomic information to facilitate the transfer of resistance genes are highlighted.

\section{Conservation and exploitation of genetic resources}

Wild tomato species represent the primary source of resistance for tomato crops. Overall, resistances to over 40 major diseases have been discovered in tomato wild relatives, and at least 20 of them have been bred into tomato cultivars (Ji et al. 2007; Robertson and Labate 2007). Solanum chilense, S.peruvianum, $S$.habrochaites and S. pimpinellifolium have proved to be the richest source of resistance genes (Foolad and Sharma 2005; Laterrot 2000; Scott and Gardner 2007). Several resources and molecular approaches have been developed to fully exploit genetic potential in tomato breeding. Molecular markers have been used to characterize and conserve genetic resources (Ercolano et al. 2005; Nuez et al. 2004) for estimating genetic relationships (Albrecht et al. 2010; Spooner et al. 2005; Zuriaga et al. 2009) and managing Genebank accessions (Tanksley and McCouch 1997). Exotic libraries for analyzing tomato wild species diversity were obtained for several species (Eshed and Zamir 1995; Monforte and Tanksley 2000). A platform for developing and screening tomato introgression lines from different wild species was obtained in the framework of the EU-SOL project (Tripodi et al. 2010). In order to isolate resistance genes involved in disease response, several cDNA libraries and genomic libraries were developed from wild tomato species. For instance, Hemaprabha and Balasaraswathi (2009) recently built up a cDNA library from $S$. peruvianum EC52071 to perform screening for resistance genes against tospoviruses. Regrettably, most are scattered throughout individual laboratories and there is no centralized recording procedure. The SGN repository reported EST data of screening performed on S. pennellii and S. habrochaites cDNA libraries (http://solgenomics.net/search/search= library). The Texas A\&M University genomic resources index reported the presence of a BAC library obtained from S. pennellii and S. cheesmaniae (http://hbz7.tamu.edu/home links/bac_est/bac.htm). Recently, oligonucleotide-based arrays have been used to identify DNA sequence polymorphisms in four different S. pimpinellifolium accessions for a study of polymorphism among S. lycopersicum and its closely related wild species (Sim et al. 2009). Rapidly increasing throughput will allow more species to be sequenced and more individuals to be genotyped at greater depth and hence with greater accuracy. We expect it to be possible to sequence tens of thousands of markers in thousands of individuals in the near future (Davey et al. 2011). Genomewide genotyping using next generation sequencing could result in a very valuable bar coding method to be explored for future needs. Insight into these questions will greatly help estimate the wealth of resistance germplasm and enable tomato resources to be preserved and utilized efficiently.

\section{Structural analysis of R-loci}

The tomato genome has been extensively explored with a view to elucidating the structure and organization of 
resistance loci. In particular, the availability of tomato molecular linkage maps has accelerated the process of disease gene localization. More than 100 loci underlying resistance traits have been mapped (Foolad 2007). By using molecular markers, chromosome walking and linkage analysis, several tomato $\mathrm{R}$-genes were isolated, including PTO, CF5, CF9, MI1-2, I2, ASC, HERO, VE, BS4 and SW5 (Brandwagt et al. 2000; Dixon et al. 1998; Ernst et al. 2002; Kawchuk et al. 2001; Milligan et al. 1998; Ori et al. 1997; Parniske et al. 1997; Schornack et al. 2004). Thanks to the modular structure of plant R-genes it was possible to perform detailed structural analyses. This information was used to shed light on many sequences homologous to genes already isolated in the same species or related species and to isolate new resistance genes. The TM2 gene was cloned by designing PCR primers on the TM2-2 gene sequence obtained by a transposon tagging approach (Lanfermeijer et al. 2003), and many genes of $C F$ series were isolated using the homology-based approach (Dixon et al. 1998; Parniske et al. 1997). Figure 1 reports the physical map based on recently released tomato genome sequences, of cloned resistance genes and of relative clusters in tomato.

Comparative approaches have revealed that resistance genes in Solanaceae are located in well-defined genomic regions (hot spots), which are organized in clusters and are conserved among related species (Ashrafi et al. 2009; Gebhardt and Valkonen 2001; Grube et al. 2000; Pan et al. 2000). Macrosynteny in the Solanaceae has been shown to be feasible. Each species has an array of R-genes targeting a given pathogen or pathogen family, and the subset of genes mapped thus far in different genera by chance is orthologous in related positions. The cloning of the late blight resistance gene $R 3 a$ from potato based on $I 2$ in tomato illustrates the potential of these comparative approaches (Huang et al. 2005). In recent years, there has been a spurt of interest in the evolutionary dynamics of disease resistance in wild Solanaceae species (Hoekstra 2009; Rose et al. 2007; Wang et al. 2008). Identification of resistance gene homologues to determine genes involved in plant defence can enrich the repertoire of R-genes available for breeding purposes (Caicedo and Schaal 2004; Riely and Martin 2001). The technique capitalizes on the presence of conserved regions of resistance genes for designing primers and isolating resistance gene homologues from different plant genomes using the polymerase chain reaction (PCR) or more advanced sequencing techniques. Discovering the means of resistance loci arrangement will be crucial for generating novel or diverse pathogen recognition capabilities in order to overcome new disease challenges. The advent of second-generation sequencing enables the production of large quantities of genome sequence data at relatively low cost. This tool can greatly facilitate comparative genomics and gene discovery. Assessing R-loci variation in a wild population or in breeding resources will be a great challenge in tomato. Target-enrichment sequencing strategies, based on polymerase chain reaction (PCR) (Tewhey et al. 2009), hybridization or molecular inversion probes (Mamanova et al. 2010) are also available. The costs and time required to generate and map them are often not justified when only a specific region of the genome needs to be investigated and merely variations detected, without isolation of the intact allele. Moreover, the variations lying in highly duplicated and highly identical R-loci are still difficult to resolve. How R-genes varied and how many of these genes are conserved remains to be determined. Genomic information can be employed

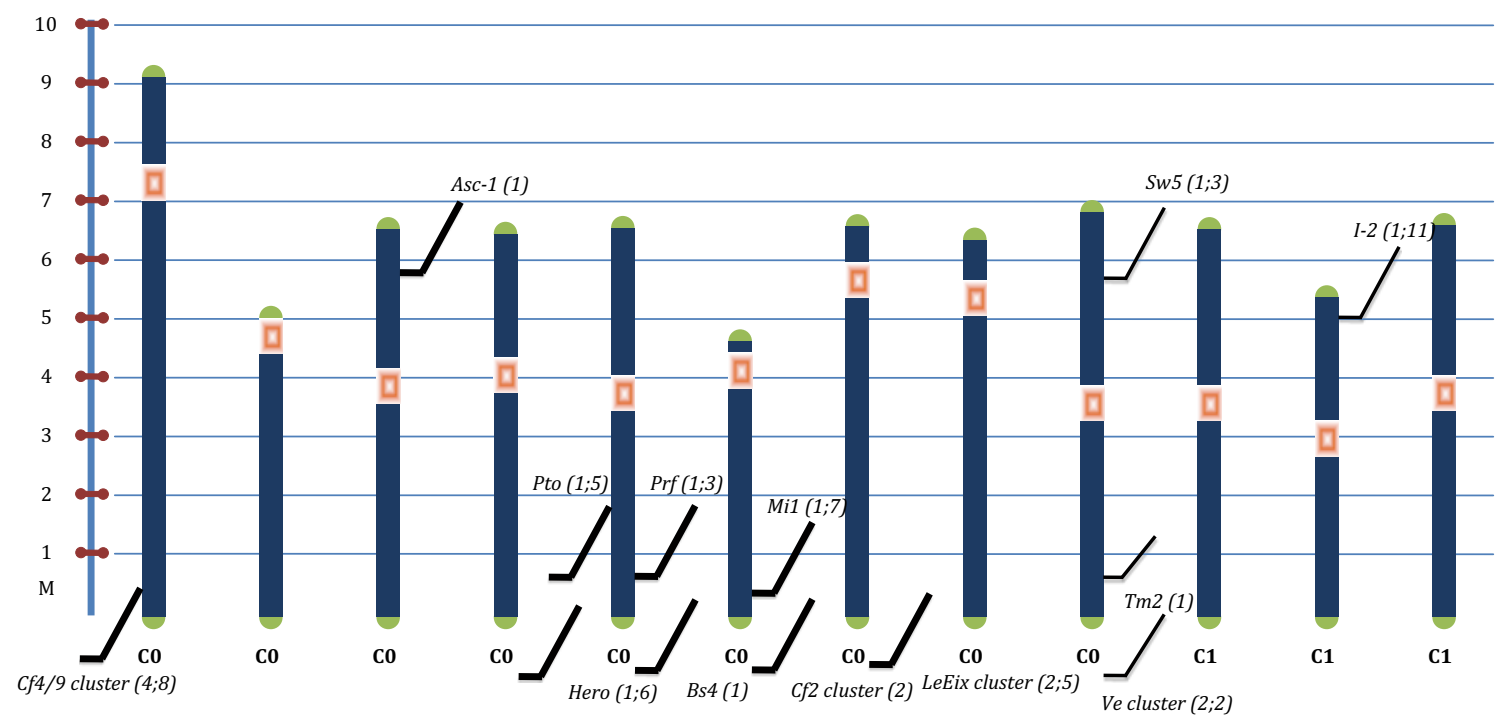

Fig. 1 Tomato physical map with indication of cloned R-gene localization. The first number in brackets reports the number of functional genes, the second the number of genes in the resistance cluster 
to link important disease resistance traits to sequence variations and incorporate this knowledge into crop improvement strategies. The interpretation of polymorphisms will require reliable methods to identify natural genetic variations, including combinations of variations, in a format suitable for downstream analysis.

\section{Dissection of R-gene mediated response}

Many genes are activated during tomato disease resistance response, and several are specific to each plant-pathogen interaction. In the past decade, dissection of plant-defence mechanisms has led to the identification and isolation of numerous tomato defence players. To exert their function, PRF, I2 and BS4 proteins physically interact with the molecular chaperon complex composed by the heat shock protein 90 (HSP90), RAR1 and SGT1 (Bhaskar et al. 2008). A lipase-like protein (EDS1) was reported as being involved in their defence mechanism as well as in CF-4 and VE resistance responses (Hu et al. 2005). A domain-swap experiment conducted between MI-1.2 and MI-1.1 suggests that activation of NB-LRR proteins is likely to require a series of conformational changes, possibly mediated via nucleotide exchange/hydrolysis by the central nucleotidebinding site (Takken and Tameling 2009). Many RLP genes can physically interact with other proteins like CF-9CITRX, LeEIX1-EDH2 and VE1-SERK3 (Fradin et al. 2009; Rivas et al. 2004). Interestingly, during the interaction between tomato and Pseudomonas syringae a series of proteins (PTO interacting proteins) were identified that play different roles in the various stages of defence response (Zhou et al. 1995). Ongoing genomic research will undoubtedly lead to further refinement of current models. Functional genomics could be very useful to investigate the features of plant-pathogen interactions. Various technologies have been developed to deduce and quantify the transcriptome, including hybridization or sequence-based approaches. Transcriptome comparison analysis has become a successful tool to gain valuable information on disease resistance response. Transcriptional changes in tomato plants during compatible and incompatible interactions with a range of pathogens were assessed (Table 1). Bhattarai et al. (2008) identified differences in JA pathway regulation in incompatible and compatible interactions with Meloidogyne spp., suggesting that the nematode is able to manipulate to its advantage by leveraging the existing cross talk between the JA and SA signalling pathways. Significant changes in expression of many unreported genes, involved in tomato-Globodera rostochiensis interaction, were detected through comparative serial analysis of gene expression (SAGE) and cDNAAFLP (Uehara et al. 2007). Microarray technology was used to underline changes occurring in tolerant interaction of the fungal wilt pathogen Verticillium dahliae (Robb et al. 2007). Van Esse et al. (2009) evidenced that photorespiration, hypoxia and glyoxylate metabolism are induced upon infection of the vascular pathogen Verticillium dahliae and repressed during interaction with the foliar pathogen Cladosporium fulvum. Catoni et al. (2009) observed differences in the ABA metabolism in tomato root and shoot transcriptional response during Tomato Spotted Wilt Virus (TSWV) infection. On tracing the expression profile of Tomato-Clavibacter michiganensis subsp. michiganensis $(\mathrm{Cmm})$ interaction, Balaji et al. (2008) evidenced that ethylene perception is involved in the regulation of $\mathrm{Cmm}$-induced symptoms. Mysore et al. (2002), using GeneCalling, explored the tomato-Pseudomonas syringae interaction, evidencing that PRF protein acts very early on during the plant-pathogen interaction. Hanssen et al. (2011) showed perturbation of pigment biosynthesis during Pepino Mosaic virus infection. Functional approaches helped identify the dynamic changes involved in hormone regulation, plant pathogen defence response, cell cycle and cytoskeleton regulation, cell wall modification, cellular signalling, transcriptional regulation and primary metabolism. Regulation of typical defence protein families like chaperone MAP kinases and protein kinases, PR proteins, ubiquitin, oxidative burst-related proteins, transcription factors, and proteins involved in primary and secondary metabolism has been highlighted (Panthee and Chen 2010). The aims of transcriptomic analysis improved with the advent of RNA-Seq technology that allows the mapping of transcribed regions at a very high resolution. All species of transcripts, including mRNAs, non-coding RNAs and small RNAs can be catalogued; the transcriptional structure of genes, in terms of their start sites, $5^{\prime}$ and $3^{\prime}$ ends, splicing patterns and other post-transcriptional modifications can be determined; the change in expression levels of each transcript under different conditions can be quantified. Future investigation of gene regulation elements, such as epigenetic DNA modifications and the plethora of small non-coding RNAs, will be useful to better direct research. For instance, it was recently shown that microRNAs (miRNAs) participate in broad regulating R-gene expression on the post-transcriptional level, and play a vital role in the network of gene expression and regulation (Zhou et al. 2011). By computational prediction and experimental validation, most of the targets of miRNAs are transcription factors. Thereby the genes targeted by miRNAs control may be regulated by pathogen response (Luan et al. 2010). In particular, a substantial network of miRNAs and resulting phased small RNA (phasiRNAs) that target NB-LRR genes was identified in legumes and others species (Zhai et al. 2011). These data suggest that miRNAs result as master regulators of 
Table 1 Main transcriptomic tomato-pathogen interaction experiments undertaken

\begin{tabular}{|c|c|c|c|c|c|c|c|}
\hline $\begin{array}{l}\text { Taxonomic } \\
\text { classification }\end{array}$ & Species & R-gene & Study & $\begin{array}{l}\text { No. of } \\
\text { differentially } \\
\text { expressed } \\
\text { genes }\end{array}$ & $\begin{array}{l}\text { Biological } \\
\text { function }\end{array}$ & $\begin{array}{l}\text { Percentage of } \\
\text { gene related } \\
\text { to a biological } \\
\text { function }(\%)\end{array}$ & References \\
\hline \multirow[t]{7}{*}{ Nematode } & \multirow[t]{5}{*}{ Meloidogyne spp. } & \multirow[t]{5}{*}{$M i$} & \multirow[t]{5}{*}{ Microarray } & \multirow[t]{5}{*}{1,941} & Transcription & 23 & \multirow{5}{*}{$\begin{array}{l}\text { Bhattarai et al. (2008) } \\
\text { Swiecicka et al. (2009) }\end{array}$} \\
\hline & & & & & Defence-related & 7 & \\
\hline & & & & & Stress response & 4 & \\
\hline & & & & & Primary metabolism & 10 & \\
\hline & & & & & Unknown & 56 & \\
\hline & \multirow[t]{2}{*}{ Globodera rostochiensis } & \multirow[t]{2}{*}{ Hero } & \multirow[t]{2}{*}{ SAGE } & \multirow[t]{2}{*}{55} & Transcription & 1 & \multirow[t]{2}{*}{ Uehara et al. (2007) } \\
\hline & & & & & Unknown & 5 & \\
\hline \multirow[t]{6}{*}{ Fungi } & \multirow[t]{3}{*}{ Cladosporium fulvum } & \multirow[t]{3}{*}{$C f$} & \multirow[t]{3}{*}{ Microarray } & \multirow[t]{3}{*}{7,073} & Transcription & 9 & \multirow[t]{3}{*}{ Van Esse et al. (2009) } \\
\hline & & & & & Stress response & 8 & \\
\hline & & & & & Primary metabolism & 58 & \\
\hline & \multirow[t]{3}{*}{ Verticillium dahliae } & \multirow[t]{3}{*}{$V e$} & \multirow[t]{3}{*}{ Microarray } & \multirow[t]{3}{*}{2,216} & Transcription & 6 & \multirow[t]{3}{*}{ Van Esse et al. (2009) } \\
\hline & & & & & Stress response & 12 & \\
\hline & & & & & Primary metabolism & 90 & \\
\hline \multirow[t]{13}{*}{ Bacteria } & \multirow{6}{*}{$\begin{array}{l}\text { Clavibacter } \\
\text { michiganensis }\end{array}$} & \multirow[t]{6}{*}{$\mathrm{Cmm}$} & \multirow[t]{6}{*}{ Microarray } & \multirow[t]{6}{*}{161} & Transcription & 19 & \multirow[t]{6}{*}{ Balaji et al. (2008) } \\
\hline & & & & & Defence-related & 36 & \\
\hline & & & & & Stress response & 20 & \\
\hline & & & & & Primary metabolism & 12 & \\
\hline & & & & & Secondary metabolism & 3 & \\
\hline & & & & & Unknown & 17 & \\
\hline & \multirow[t]{7}{*}{ Pseudomonas syringae } & \multirow[t]{7}{*}{ Pto } & Gene & 432 & Transcription & 6 & Mysore et al. (2002) \\
\hline & & & calling & & Defence-related & 10 & \\
\hline & & & & & Stress response & 17 & \\
\hline & & & & & Primary metabolism & 30 & \\
\hline & & & & & Secondary metabolism & 8 & \\
\hline & & & & & Miscellaneous & 4 & \\
\hline & & & & & Unknown & 24 & \\
\hline Virus & $\begin{array}{l}\text { Tomato Spotted Wilt } \\
\text { Virus }\end{array}$ & $S w-5$ & Microarray & 2,962 & $\begin{array}{l}\text { Defence and stress } \\
\text { response }\end{array}$ & 23 & Catoni et al. (2009) \\
\hline & & & & & Primary metabolism & 46 & \\
\hline & & & & & Secondary metabolism & 22 & \\
\hline & & & & & Signal transduction & 9 & \\
\hline
\end{tabular}

Information is reported about pathogens, involved R-genes, number of differentially expressed genes, functional annotations and test references

this large gene family via the targeting of highly conserved, protein-coding motifs. An extensive study for identifying and profiling the expression of miRNAs under various pathological conditions could better elucidate their specific role. Furthermore, many biological questions can only be addressed at the protein level as the presence of either a gene or its mRNA is no guarantee of a role in cellular activity. Large-scale proteome data sets are an important resource for the better understanding of protein functions in cellular systems. Proteomics has contributed to defining the specific functions of genes and proteins involved in plantpathogen interactions. A group of molecular chaperones were identified in resistant plants challenged by bacteria
(Coaker et al. 2004; Afroz et al. 2009; Dahal et al. 2010). Pr proteins in tomato plants challenged by Fusarium oxysporum (Houterman et al. 2007) and virus (Rodrigo et al. 1991) during interaction response were identified. However, technical limitations in proteomic studies need to be overcome in order to advance our knowledge on protein expression (Afroz et al. 2011). Over the last few years also the parallel assessment of the levels of a broad range of metabolites have been documented in tomato-pathogen interaction (López-Gresa et al. 2010). Direct chemical screening proved to be a powerful way to characterize genetic diversity in trichome-specialized metabolism (Schilmiller et al. 2010). The ability to screen a wide range 
of metabolites at once is very useful. Not only does this enable the detection of unknown traits but it also facilitates a greater understanding of the metabolic network and how this interacts with phenotypes (Fernie and Schauer 2009). In addition, large-scale collections of bioresources, such as mass-produced mutant lines and clones of full-length cDNAs and their integrative databases, could be useful for designing experiments (Aoki et al. 2010, Saito et al. 2011).

In the last few years, several research efforts have sought to give a comprehensive view of specific disease resistance responses in tomato. The amount of information about different aspects of the biology of this crop, as well as the many tools available for them and the number of scientists dedicated to their research creates a synergism that puts them at great advantage over other plant species. Current achievements in this research area have greatly advanced our understanding of tomato defence responses. A significant fraction of proteins identified through functional approaches lack functional information, highlighting the limitation in our current understanding of the defence process (Jones and Dang 2006). Characterization of the single genes is essential to provide biological insights and to further support established networks. Overexpression of tomato PTO proved to enhance expression of mitogen-activated protein kinases (MAPKs), conferring resistance against Xanthomonas campestris pv vesicatoria and Cladosporium fulvum (Tang et al. 1999). Tobacco N (Whitham et al. 1996), potato R1 (Faino et al. 2010) and pepper BS2 R-genes (Tai et al. 1999) showed they were specifically expressed also in tomato. Furthermore, the $\mathrm{OxO}$ gene (wheat oxalate oxidase) reduces light blight symptoms and improves Botrytis cinerea and Sclerotinia sclerotiorum resistance (Walz et al. 2008), and the sweet pepper ferredoxin-I protein (PFLP) improves resistance to Ralstonia solanacearum (Huang et al. 2007). Exploring mutant collections in order to develop Targeting-induced local lesions in genome (TILLING) platforms could represent a valuable high-throughput reverse genetic strategy to screen for point mutations in specific regions of targeted genes (Minoia et al. 2010). Furthermore, an effort to make knockout collections and silencing experiments could also be useful to identify unique features of each pathosystem. Techniques like artificial micro-RNA expression (Ruiz-Ferrer and Voinnet 2009; Ultzen et al. 1995), RNA interference (RNAi) (Bendahmane and Gronenborn 1997) and virus-induced gene silencing (VIGS) (Fu et al. 2005) could lend an impetus to basic plant-pathogen interaction studies and to improve plant-defence responses (Oh and Martin 2011).

\section{Emerging genomics tools}

High-throughput sequencing and computational technologies have marked the beginning of a new genomics era.
The genomic approach to exploring repertoires of resistance genes could clarify numerous molecular and evolutionary mechanisms for this gene family. Use of such technologies will make it easier to design diagnostic tests, conduct comparative and functional analysis and perform breeding by in silico design. DNA sequencing technologies are being updated at a blistering pace. These methodologies are transforming what we can do, how we should do it, and how much we can do in our own experiments. Because most platforms can be used for different applications, economics, length of time to acquire data, downstream analysis constraints become important for selecting a platform (Glenn 2011). As the number and variety of instruments increase and costs continue to decrease, we will become constrained only by our knowledge of the systems and our creativity to develop and adapt techniques to obtain data efficiently (Braeutigam and Gowik 2010).

Tomato represents one of best-explored model plants for studying defence response systems. Its genome sequence was recently released by the International SOL consortium using a Whole Genome Shotgun approach, including $\sim 350,000 \mathrm{BAC}$ and fosmid end-sequence pairs. The draft versions are accessible from the SOL Genomics Network (http://solgenomics.net/). New insights into the plant immune system can be achieved through genomic approaches. Starting from raw data it is possible to select a specific set of candidate genes putatively involved in biotic stress response. Expression levels of specific genes, differential splicing, and allele-specific expression of transcripts can be accurately determined by RNA-Seq experiments. All these attributes are not readily achievable via previously widespread hybridization-based or tag sequence-based approaches. However, the unprecedented level of sensitivity and the large amount of available data produced by NGS (next generation sequencing) platforms provide clear advantages as well as new challenges and issues.

Global information on tomato defence responses can create a body of knowledge concerning the frequency of relevant sequences, their evolution and possible functions. The development of tools to pool information obtained through different systems, to connect and to compare information in molecular biology and biochemistry, could be useful to start to delineate a systems biology approach in order to understand the plant-defence mechanism, thereby allowing new breeding methods to be designed. A combinatorial approach using multiple omics platforms and integration of their outcomes is now an effective strategy for clarifying molecular systems integral for plant improvement. Promotion of comparative genomics among model and applied plants allows us to grasp the biological properties of each species and to accelerate gene discovery and functional analyses of genes (Mochida and Shinozaki 
2010). Interdisciplinary approaches can be undertaken using these resources for an in-depth study of the plant immune system. However, little attention has been given to integrating conceptually all of the related components identified in any plant-pathogen interaction. The most important point for a network construction is to obtain reliable analytical results based on sufficient experimental data. Signal transduction pathways should be connected and regulatory relationships between signals from elicitors and signal molecules need to be investigated. Several studies have been performed to draw out resistance gene features, analyze the level of conservation between organisms and to understand how they work. Collecting all the existing data in a repository could be a good starting point to conduct further studies. A specific online resource, the plant resistance gene (PRG) database was designed for molecular and in silico studies on plant R-genes (Sanseverino et al. 2010a). This manually curated database holds well characterized and candidate plant disease resistance genes belonging to nearly 200 plant species. Users can download reference genes of interest to design primers to amplify homologous genes in their species of interest or simply use various queries provided to get further information on domains, motifs and bibliography. Moreover, comparative studies and plant-pathogen interaction analysis can be performed through Pathoplant, that is, a database on plant-pathogen interactions and components of signal transduction pathways related to plant pathogenesis. Pathoplant also harbours gene expression data from Arabidopsis thaliana microarray experiments to enable the search for specific genes regulated upon pathogen infection or elicitor treatment (Bülow et al. 2009). The tomato functional genomics database also offers a valuable collection of tomato microarray experiments (Fei et al. 2011). The Dana Farber Cancer Institute Gene Index Database, also known as the "TIGR EST database" located at http:// compbio.dfci.harvard.edu/tgi/tgipage.htm, the Mibase at http://www.kazusa.or.jp/jsol/microtom (Yano et al. 2006) and the TomatoEST db (D'agostino et al. 2007) can be used to manage and explore expressed sequences. ORTom, tomato-centred EST data-mining based on conserved coexpression, can be used to predict functional relationships among genes and to prioritize candidate genes for targeted studies (Miozzi et al. 2010). Moreover, the Solanaceae Genomic Network (SOL) offers several useful bioinformatics tools to make synteny studies (Mueller et al. 2005). It makes information available in an intuitive comparative format, thereby facilitating a systems approach to investigations into the basis of adaptation and phenotypic diversity.

The tomato reference genome is available and several tomato genomes have begun to be sequenced (SOL100 initiative; http://solgenomics.net/organism/sol100/view). A sequencing-based approach using these promising technologies could lead to identifying thousands of sequences of putative R-genes in a wide array of species. In principle, there are two possible approaches to discovering new genes based on genomic sequence and based on transcriptome sequences. A low coverage is required for the identification of genes and gene promoters. Reads of any length can be mapped onto the reference genome, and several algorithms for SNPs discovering have been developed. In addition, identification of related disease resistance genes from expressed gene messages (mRNA) would be compelling evidence for a potential function. Routine use of massively parallel sequencing will require higher accuracy, better ways to select genomic subsets of interest, and improvements in processing speed. Selection of accurate SNP sites, e.g. with high-quality value and/or with high coverage of sequence fragments, is also important (Shirasawa et al. 2010). High-throughput genotyping and phenotyping projects of large populations require sophisticated laboratory information management systems. In order to obtain valuable information, data need to be handled with care.

The ability to screen a wide range of metabolites at once will also be very useful. Several recent studies have illustrated the utility of combining data from metabolomics with those from other genomics platforms to provide new insights on both gene annotation (Mintz-Oron et al. 2008) and regulation in complex biological systems (Osorio et al. 2011; Klee 2010). These approaches have resulted in the identification of numerous candidate genes. The aim of these non-targeted 'omic' technologies is to extend our understanding beyond the analysis of separate parts of the system, in contrast to traditional reductionist hypothesisdriven approaches. The integration of genotyping, pheno/ morphotyping and the analysis of the molecular phenotype using metabolomics, proteomics and transcriptomics will reveal a novel understanding of plant genome and its interaction with the environment. Core facilities handling cooperative projects will require a straightforward solution to manage combined information. Due to these great advances in technologies it now seems to be the perfect time to exploit genome information to make new achievements in this field.

\section{Advancements in breeding strategy design}

The necessary reliance on resistance processes to work out the genetic basis of variation for resistance traits is not limiting, given the extensive work conducted in solanaceae species. DNA markers tightly linked to resistance loci have long been used for marker-assisted selection (MAS) to incorporate these valuable traits in new tomato varieties. They help carry a more efficient and precise transfer of the 
Fig. 2 A schematic view of combined genomic strategies to obtain tomato resistance cultivars



R-gene/QTL, reducing the negative effects of linkage drag (St Clair 2010). MAS tomato selection has also proved to accelerate the pyramiding of desirable genes and QTLs for different traits (Barone and Frusciante 2007). To increase selection efficiency, an approach that combines the use of high-throughput genomic analysis with phenotypic analysis could help identify candidate genes for genomics-assisted breeding (Fig. 2).

A high-precision breeding approach can be achieved using a tomato physical map that allows specific traits to be detected. Merging literature data, genetic information and prediction data is an efficient way to trace tomato R-genes (Sanseverino et al. 2010b). So-called ' jackpot', cultivars can be seen as a source of cassettes of resistances and contain clusters of many tightly-linked resistances (Grube et al. 2000). The targeted genome region can be in silico selected, well characterized by molecular work and transferred during whole genome selection (WGS). To coordinate high-density SNP genotyping of varieties and lines and organize precise phenotyping efforts for association studies a comprehensive tomato diversity survey can be very useful (Robbins et al. 2011). Allele-specific markers should be informative whatever the genetic background, but sometimes the presence of very similar R-gene paralogues could invalidate diagnostic testing as many resistance genes remain in (large) clusters, containing highly similar gene members. The complex arrangement of the disease-resistance loci $I 2, M I$ and $S W-5$ genes in tomato (Dianese et al. 2010; El Mohtar et al. 2007; Simons et al. 1998) has shown that design of specific primers can be very difficult. The availability of linked markers, allele-specific markers and sequence data sets can facilitate the screening 
of varieties and populations for many resistance genes at the same time.

The acceleration in mapping and sequencing techniques and the decreasing in costs in NGS and metabolomicsbased phenotyping, will extend the possibilities of gene and marker discovery and genome-wide quantification of gene expression. Integrating results from metabolic and morphological profiling proves to be a powerful strategy for crop improvement. Most metabolomics approaches are unbiased; the profiles they produce contain many unannotated peaks, representing unknown metabolites. Therefore, it seems likely that the power of metabolomics as a platform for the selection of breeding material can only improve. The measurement of the dynamic molecular phenotype should be connected to the static genotype information. Based on the integration of genotype data, especially in conjunction with SNP measurements, a systematic investigation of this intimate relationship is possible by means of dynamic transcriptomic, proteomic and metabolomic data. Recently, a systematic approach was proposed explicitly on the basis of a genotype-phenotypeequation (Weckwerth 2011).

Importance of the genetic background should not be underestimated. Gene dosage effects, non-allelic and epistatic interactions, and host background genotypic factors could influence the inheritance patterns of R-genes and also affect the phenotypes they mediate. Detailed analysis of parental lines can help to define the molecular, biochemical and phenotypic components of disease response. A comprehensive understanding of the process will translate into knowledge-based approaches in genome-assisted breeding approaches. A current challenge in interpreting genomewide association studies is to establish the mechanistic links between the measured genotype and observed phenotype (Tian et al. 2011). This information provides an opportunity for determining reliability of using different 'omic' profiling techniques. In silico procedures are expected to improve the breeding strategies, especially when the numbers of genotypes and traits to assess are huge. After generating and analyzing new populations, information from informatics support could help understand and interpret the resulting data. The genetic advance achieved through genomic selection depends on the ability to capture superior alleles, the repeatability of the trait and the selection pressure imposed. Parental line selection in breeding hybrid varieties is an important task. An important criterion for the choice of parents is their genetic distance. The relatedness of parents can be researched by comparing their genome. Those parents with a polymorphism in target traits should then be crossed.

Modern breeding is a dynamic and evolving research discipline. Traditional selection schemes should be modified and adapted for computational methods. Algorithms that generate both general and detailed scores of each trait for each genotype should be developed for handling large data sets and methods for estimating recombination rates, and recombination hotspots should be identified. The individuals can be sorted with respect to their general scores to extract resistant genotypes with the desired traits. Germplasm should then be selected based on the likelihood the lines will produce valuable new genetic combinations.

\section{Conclusions}

Exploring the genetic and genomic basis of genomic variation can be useful for identifying new resistance genes and clarifying their mechanisms of action. Enormous advances have been made in our knowledge of R-genes and in elucidating the role and mechanism of action of genes involved in the tomato defence response. New genomic technologies, including high-throughput DNA sequencing, large-scale expression data production and comparative hybridization techniques have led to the expansion of available data. Methods for identifying modification events and interactions in the plant proteome, and for measuring the abundance of many metabolites simultaneously are also available. The overall reduction in costs has led to experiments being designed in which R-gene investigation will prove more productive. Such comprehensive biological vision provides an excellent starting point for designing experiments, generating hypotheses or conceptualization of model based on integrated knowledge. In this context, extensive information for different purposes is available in database repositories and constitutes a valuable set of data for studies, characterization and use of resistance genes in breeding programs.

Acknowledgments We thank M. Walters for editing the manuscript. Contribution no. 260 from the DISPAPA.

Open Access This article is distributed under the terms of the Creative Commons Attribution License which permits any use, distribution, and reproduction in any medium, provided the original author(s) and the source are credited.

\section{References}

Afroz A, Khan MR, Ahsan N, Komatsu S (2009) Comparative proteomic analysis of bacterial wilt susceptible and resistant tomato cultivars. Peptides 30:1600-1607

Afroz A, Ali GM, Mir A, Komatsu S (2011) Application of proteomics to investigate stress-induced proteins for improvement in crop protection. Plant Cell Rep 30:745-763

Albrecht E, Escobar M, Chetelat RT (2010) Genetic diversity and population structure in the tomato-like nightshades Solanum lycopersicoides and S. sitiens. Ann Bot 105:535-554 
Aoki K, Yano K, Suzuki A, Kawamura S, Sakurai N, Suda K, Kurabayashi A, Suzuki T, Tsugane T, Watanabe M, Ooga K, Torii M, Narita T, Shin-I T, Kohara Y, Yamamoto N, Takahashi H, Watanabe Y, Egusa M, Kodama M, Ichinose Y, Kikuchi M, Fukushima S, Okabe A, Arie T, Sato Y, Yazawa K, Satoh S, Omura T, Ezura H, Shibata D (2010) Large-scale analysis of full-length cDNAs from the tomato (Solanum lycopersicum) cultivar Micro-Tom, a reference system for the Solanaceae genomics. BMC Genomics 11:210

Ashrafi H, Kinkade M, Foolad MR (2009) A new genetic linkage map of tomato based on a Solanum lycopersicum $\times$ S. pimpinellifolium RIL population displaying locations of candidate pathogen response genes. Genome 52:935-956

Balaji V, Mayrose M, Sherf O, Jacob-Hirsch J, Eichenlaub R, Iraki N, Manulis-Sasson S, Rechavi G, Barash I, Sessa G (2008) Tomato transcriptional changes in response to Clavibacter michiganensis subsp. michiganensis reveal a role for ethylene in disease development. Plant Physiol 146:1797-1809

Barone A, Frusciante L (2007) Molecular marker-assisted selection for resistance to pathogens in tomato. In: Guimarães (ed) MARKER-ASSISTED SELECTION: Current status and future perspectives in crops, livestock, forestry and fish FAO, Rome, pp 151-164

Bendahmane M, Gronenborn B (1997) Engineering resistance against tomato yellow leaf curl virus (TYLCV) using antisense RNA. Plant Mol Biol 33:351-357

Bhaskar PB, Raasch JA, Kramer LC, Neumann P, Wielgus SM (2008) Sgtl, but not Rarl, is essential for the RB-mediated broadspectrum resistance to potato late blight. BMC Plant Biol. doi: 10.1186/1471-2229-8

Bhattarai KK, Xie QG, Mantelin S, Bishnoi U, Girke T, Navarre DA, Kaloshian I (2008) Tomato susceptibility to root-knot nematodes requires an intact jasmonic acid signaling pathway. Mol Plant Microbe In 21:1205-1214

Braeutigam A, Gowik U (2010) What can next generation sequencing do for you? Next generation sequencing as a valuable tool in plant research. Plant Biol 12(6):831-841

Brandwagt BF, Mesbah LA, Takken FL, Laurent PL, Kneppers TJ, Hille J, Nijkamp HJ (2000) A longevity assurance gene homolog of tomato mediates resistance to Alternaria alternata f. sp. lycopersici toxins and fumonisin B1. Proc Natl Acad Sci USA 97:4961-4966

Bülow L, Engelmann S, Schindler M, Hehl R (2009) AthaMap, integrating transcriptional and post-transcriptional data. Nucleic Acids Res 37:983-986

Caicedo AL, Schaal BA (2004) Heterogeneous evolutionary processes affect $\mathrm{R}$ gene diversity in natural populations of Solanum pimpinellifolium. Proc Natl Acad Sci USA 101:17444-17449

Catoni M, Miozzi L, Fiorilli V, Lanfranco L, Accotto GP (2009) Comparative analysis of expression profiles in shoots and roots of tomato systemically infected by Tomato spotted wilt virus reveals organ-specific transcriptional responses. Mol Plant Microbe In 22:1504-1513

Coaker GL, Willard B, Kinter M, Stockinger EJ, Francis DM (2004) Proteomic analysis of resistance mediated by $\mathrm{Rcm} 2.0$ and $\mathrm{Rcm}$ 5.1 , two loci controlling resistance to bacterial canker of tomato. Mol Plant Microbe In 17:1019-1028

D'Agostino N, Aversano M, Frusciante L, Chiusano ML (2007) TomatEST database: in silico exploitation of EST data to explore expression patterns in tomato species. Nucleic Acids Res 35:D901-D905

Dahal D, Pich A, Braun HP, Wydra K (2010) Analysis of cell wall proteins regulated in stem of susceptible and resistant tomato species after inoculation with Ralstonia solanacearum: a proteomic approach. Plant Mol Biol 73:643-658
Davey JW, Hohenlohe PA, Etter PD, Boone JQ, Catchen JM, Blaxter ML (2011) Genome-wide genetic marker discovery and genotyping using next-generation sequencing. Nat Rev Genet 12(7):499-510. doi:10.1038/nrg3012

Desneux N, Wajnberg E, Wyckhuys K, Burgio G, Arpaia S, NarváezVasquez C, Gonzalez-Cabrera J, Catalán-Ruescas D, Tabone E, Frandon J, Pizzol J, Poncet C, Cabello T, Urbaneja A (2010) Biological invasion of European tomato crops by Tuta absoluta: ecology, geographic expansion and prospects for biological control. J Pestic Sci 3:197-215

Dianese É, de Fonseca M, Goldbach R, Kormelink R, Inoue-Nagata A, Resende R, Boiteux L (2010) Development of a locusspecific, co-dominant SCAR marker for assisted-selection of the $\mathrm{Sw}-5$ (Tospovirus resistance) gene cluster in a wide range of tomato accessions. Mol Breeding 25:133-142

Dixon MS, Hatzixanthis K, Jones DA, Harrison K, Jones JD (1998) The tomato $C f-5$ disease resistance gene and six homologs show pronounced allelic variation in leucine-rich repeat copy number. Plant Cell 10:1915-1925

El Mohtar CA, Atamian HS, Dagher RB, Abou-Jawdah Y, Salus MS, Maxwell DP (2007) Marker-assisted selection of tomato genotypes with the $I-2$ gene for resistance to Fusarium oxysporum $f$. sp. lycopersici Race 2. Plant Dis 91:758-762

Ercolano MR, Sebastiano A, Monti L, Frusciante L, Barone A (2005) Molecular characterization of Solanum habrochaites accessions. J Genet Breed 59:15-20

Ernst K, Kumar A, Kriseleit D, Kloos DU, Phillips MS, Ganal MW (2002) The broad-spectrum potato cyst nematode resistance gene (Hero) from tomato is the only member of a large gene family of NBS-LRR genes with an unusual amino acid repeat in the LRR region. Plant J 31:127-136

Eshed Y, Zamir D (1995) An introgression line population of Lycopersicon pennellii in the cultivated tomato enables the identification and fine mapping of yield-associated QTL. Genetics 141:1147-1162

Faino L, Carli P, Testa A, Cristinzio G, Frusciante L, Ercolano M (2010) Potato $R 1$ resistance gene confers resistance against Phytophthora infestans in transgenic tomato plants. Eur J Plant Pathol 128:233-241

Fei ZJ, Joung JG, Tang XM, Zheng Y, Huang MY, Lee JM, McQuinn R, Tieman DM, Alba R, Klee HJ, Giovannoni JJ (2011) Tomato functional genomics database: a comprehensive resource and analysis package for tomato functional genomics. Nucleic Acids Res 39:D1156-D1163

Fernie AR, Schauer N (2009) Metabolomics-assisted breeding: a viable option for crop improvement? Trends Genet 25:39-48

Foolad M (2007) Genome mapping and molecular breeding of tomato. Int J Plant Genomics 2007:1-52

Foolad M, Sharma A (2005) Molecular markers as selection tools in tomato breeding. Acta Hortic 695:225-240

Fradin EF, Zhang Z, Juarez Ayala JC, Castroverde CDM, Nazar RN, Robb J, Liu C-M, Thomma BPHJ (2009) Genetic dissection of Verticillium wilt resistance mediated by tomato Ve1. Plant Physiol 150:320-332

Fu D, Zhu B, Zhu H, Jiang W, Luo Y (2005) Virus-induced gene silencing in tomato fruit. Plant J 43:299-308

Gebhardt C, Valkonen JP (2001) Organization of genes controlling disease resistance in the potato genome. Annu Rev Phytopathol 39:79-102

Glenn TC (2011) Field guide to next-generation DNA sequencers. Mol Ecol Resour 11(5):759-769

Grube R, Radwanski E, Jahn M (2000) Comparative genetics of disease resistance within the Solanaceae. Genetics 155:873-887

Hanssen IM, Lapidot M, Thomma BPHJ (2010) Emerging viral diseases of tomato crops. Mol Plant Microbe In 23:539-548 
Hanssen IM, Peter van Esse H, Ballester A, Hogewoning SW, Parra NO, Paeleman A, Lievens B, Bovy AG, Thomma BPHJ (2011) Differential tomato transcriptomic responses induced by pepino mosaic virus isolates with differential aggressiveness. Plant Physiol 156:301-318. doi:10.1104/pp.111.173906

Hemaprabha E, Balasaraswathi R (2009) Construction and analysis of cDNA library for tospovirus resistance genes. Adv Biotech $8: 9-22$

Hoekstra R (2009) Exploring the natural biodiversity of potato for late blight resistance. Potato Res 52:237-244

Houterman PM, Speijer D, Dekker HL, Koster CGD, Cornelissen BJC, Rep M (2007) The mixed xylem sap proteome of Fusarium oxysporium infected tomato plants. Mol Plant Pathol 8:215-221

Hu G, deHart AK, Li Y, Ustach C, Handley V, Navarre R, Hwang CF, Aegerter BJ, Williamson VM, Baker B (2005) EDS1 in tomato is required for resistance mediated by TIR-class $\mathrm{R}$ genes and the receptor-like R gene Ve. Plant J 42:376-391

Huang S, van der Vossen EA, Kuang H, Vleeshouwers VG, Zhang N, Borm TJ, van Eck HJ, Baker B, Jacobsen E, Visser RG (2005) Comparative genomics enabled the isolation of the $R 3 a$ late blight resistance gene in potato. Plant J 42:251-261

Huang H, Liu C, Lee M, Kuo C, Chen H, Ger M, Tsai Y, Chen Y, Lin M, Feng T (2007) Resistance enhancement of transgenic tomato to bacterial pathogens by the heterologous expression of sweet pepper ferredoxin-I protein. Phytopathology 97:900-906

Ji Y, Scott J, Hanson P, Graham E, Maxwell D (2007) Sources of resistance, inheritance, and location of genetic loci conferring resistance to members of the tomato-infecting begomoviruses. In: czosnekh edn tomato yellow leaf curl virus disease. Springer Netherlands, pp 343-362

Jones JDG, Dang JL (2006) The plant immune system. Nature 444:323-329

Kawchuk LM, Hachey J, Lynch DR, Kulcsar F, van Rooijen G, Waterer DR, Robertson A, Kokko E, Byers R, Howard RJ, Fischer R, Prufer D (2001) Tomato Ve disease resistance genes encode cell surface-like receptors. P Natl Acad Sci U S A 98:6511-6515

Klee HJ (2010) Improving the flavor of fresh fruits: genomics, biochemistry, and biotechnology. New Phytol 187:44-56

Labate J, Grandillo S, Fulton T, Muños S, Caicedo A, Peralta I, Ji Y, Chetelat R, Scott J, Gonzalo M, Francis D, Yang W, van der Knaap E, Baldo A, Smith-White B, Mueller L, Prince J, Blanchard N, Storey D, Stevens M, Robbins M, Wang J, Liedl B, O'Connell M, Stommel J, Aoki K, Iijima Y, Slade A, Hurst S, Loeffler D, Steine M, Vafeados D, McGuire C, Freeman C, Amen A, Goodstal J, Facciotti D, Van Eck J, Causse M (2007) Genome mapping and molecular breeding in plants. In: kolec (ed) genome mapping and molecular breeding in plants, pp 1-96

Lanfermeijer FC, Dijkhuis J, Sturre MJ, de Haan P, Hille J (2003) Cloning and characterization of the durable tomato mosaic virus resistance gene $T m-2(2)$ from Lycopersicon esculentum. Plant Mol Biol 52:1037-1049

Laterrot H (2000) Disease resistance in tomato: practical situation. Acta Physiol Plant 22:328-331

López-Gresa MP, Maltese F, Bellés JM, Conejero V, Kim HK, Choi YH, Verpoorte R (2010) Metabolic response of tomato leaves upon different plant-pathogen interactions. Phytochem Analysis 21(1):89-94

Luan I, Han Y, Zhu H, Shao Y, Chen A, Tian H, Luo Y, Zhu B (2010) Computational predicting novel MicroRNAs in tomato and validating with RT-PCR Russ. J Plant Physl 57(4):469-479

Lukyanenko A (1991) Disease resistance in tomato. Monographs on Theor Appl Genet 14:99-119

Mamanova L, Coffey AJ, Scott CE, Kozarewa I, Turner EH, Kumar A, Howard E, Shendure J, Turner DJ (2010) Target-enrichment strategies for next-generation sequencing. Nat Methods 7:111-118

Matsukura C, Aoki K, Fukuda N, Mizoguchi T, Asamizu E, Saito T, Shibata D, Ezura H (2008) Comprehensive resources for tomato functional genomics based on the miniature model tomato micro-tom. Curr Genomics 9:436-443

Milligan SB, Bodeau J, Yaghoobi J, Kaloshian I, Zabel P, Williamson VM (1998) The root knot nematode resistance gene $M i$ from tomato is a member of the leucine zipper, nucleotide binding, leucine-rich repeat family of plant genes. Plant Cell 10:13071319

Minoia S, Petrozza A, D’Onofrio O, Piron F, Mosca G, Sozio G, Cellini F, Bendahmane A (2010) A new mutant genetic resource for tomato crop improvement by TILLING technology. BMC Res Notes 3:69

Mintz-Oron S, Mandel T, Rogachev I, Feldberg L, Lotan O, Yativ M, Wang Z, Jetter R, Venger I, Adato A, Aharoni A (2008) Gene expression and metabolism in tomato fruit surface tissues. Plant Physiol 147:823-851

Miozzi L, Provero P, Accotto GP (2010) ORTom: a multi-species approach based on conserved co-expression to identify putative functional relationships among genes in tomato. Plant Mol Biol 73:519-532

Mochida K, Shinozaki K (2010) Genomics and bioinformatics resources for crop improvement. Plant Cell Physiol 51(4):497523

Monforte AJ, Tanksley SD (2000) Development of a set of near isogenic and backcross recombinant inbred lines containing most of the Lycopersicon hirsutum genome in a L. esculentum genetic background: a tool for gene mapping and gene discovery. Genome 43:803-813

Mueller L, Solow T, Taylor N, Skwarecki B, Buels R, Binns J, Lin C, Wright M, Ahrens R, Wang Y, Herbst E, Keyder E, Menda N, Zamir D, Tanksley S (2005) The SOL genomics network: a comparative resource for Solanaceae biology and beyond. Plant Physiol 138:1310-1317

Mysore KS, Crasta OR, Tuori RP, Folkerts O, Swirsky PB, Martin GB (2002) Comprehensive transcript profiling of Pto- and Prfmediated host defense responses to infection by Pseudomonas syringae pv. tomato. Plant J 32:299-315

Nuez F, Prohens J, Blanca J (2004) Relationships, origin, and diversity of Galapagos tomatoes: implications for the conservation of natural populations. Am J Bot 91:86-99

Oh CS, Martin GB (2011) Effector-triggered immunity mediated by the Pto kinase. Trends Plant Sci 16:132-140

Ori N, Eshed Y, Paran I, Presting G, Aviv D, Tanksley S, Zamir D, Fluhr R (1997) The I2C family from the wilt disease resistance locus $I 2$ belongs to the nucleotide binding, leucine-rich repeat superfamily of plant resistance genes. Plant Cell 9:521-532

Osorio S, Alba R, Damasceno CMB, Lopez-Casado G, Lohse M, Zanor MI, Tohge T, Usadel B, Rose JKC, Fei Z, Giovannoni JJ, Fernie AR (2011) Systems biology of tomato fruit development: combined transcript, protein, and metabolite analysis of tomato transcription factor (nor, rin) and ethylene receptor $(\mathrm{Nr})$ mutants reveals novel regulatory interactions. Plant Physiol 157:405-425

Pan Q, Liu YS, Budai-Hadrian O, Sela M, Carmel-Goren L, Zamir D, Fluhr R (2000) Comparative genetics of nucleotide binding siteleucine rich repeat resistance gene homologues in the genomes of two dicotyledons: tomato and arabidopsis. Genetics 155:309-322

Panthee DR, Chen F (2010) Genomics of fungal disease resistance in tomato. Curr Genomics 11:30-39

Parniske M, Hammond-Kosack KE, Golstein C, Thomas CM, Jones DA, Harrison K, Wulff BB, Jones JD (1997) Novel disease resistance specificities result from sequence exchange between 
tandemly repeated genes at the $C f-4 / 9$ locus of tomato. Cell 91:821-832

Postel S, Kemmerling B (2009) Plant systems for recognition of pathogen-associated molecular patterns. Semin Cell Dev Biol 20:1025-1031

Riely B, Martin G (2001) Ancient origin of pathogen recognition specificity conferred by the tomato disease resistance gene Pto. Proc Natl Acad Sci USA 98:2059-2064

Rivas S, Rougon-Cardoso A, Smoker M, Schauser L, Yoshioka H, Jones J (2004) CITRX thioredoxin interacts with the tomato $C f-9$ resistance protein and negatively regulates defence. EMBO $\mathrm{J}$ 23:2156-2165

Robb J, Lee B, Nazar RN (2007) Gene suppression in a tolerant tomato-vascular pathogen interaction. Planta 226:299-309

Robbins MD, Sim SC, Yang W, Van Deynze A, van der Knaap E, Joobeur T, Francis DM (2011) Mapping and linkage disequilibrium analysis with a genome-wide collection of SNPs that detect polymorphism in cultivated tomato. J Exp Bot 62(6):1831-1845. doi:10.1093/jxb/erq36

Robertson L, Labate J (2007) Genetic resources of tomato (Lycopersicon esculentum var. esculentum) and wild relatives. In: Razdan M, Mattoo A (eds) Genetic Improvement of Solanaceous Crops. USA, Enfield, pp 25-75

Rodrigo I, Vera P, Frank R, Conejero V (1991) Identification of the viroid-induced tomato pathogenesis-related (PR) protein P23 as the thaumatin-like tomato protein NP24 associated with osmotic stress. Plant Mol Biol 16:931-934

Rose LE, Michelmore RW, Langley CH (2007) Natural variation in the Pto disease resistance gene within species of wild tomato (Lycopersicon). II. Population genetics of Pto. Genetics 175:1307-1319

Ruiz-Ferrer V, Voinnet O (2009) Roles of plant small RNAs in biotic stress responses. Annu Rev Plant Biol 60:485-510

Saito T, Ariizumi T, Okabe Y, Asamizu E, Hiwasa-Tanase K, Fukuda N, Mizoguchi T, Yamazaki Y, Aoki K, Ezura H (2011) Tomatoma: a novel tomato mutant database distributing microtom mutant collections. Plant Cell Physiol 52(2):283-296

Sanseverino W, Roma G, De Simone M, Faino L, Melito S, Stupka E, Frusciante L, Ercolano MR (2010a) PRGdb: a bioinformatics platform for plant resistance gene analysis. Nucleic Acids Res 38:D814-D821

Sanseverino W, Rombauts S, Van Der Peer Y, Frusciante L, Ercolano MR $(2010$ b) A combined approach for tagging R-genes candidate loci in tomato. In: The 7th Solanaceae Conference, Dundee, p 66

Schilmiller AL, Shi F, Kim J, Charbonneau AL, Holmes D, Jones AD, Last RL (2010) Mass spectrometry reveals widespread diversity in trichome specialized metabolites of tomato chromosomal substitution lines. Plant J 62:391-403

Schornack S, Ballvora A, Gurlebeck D, Peart J, Baulcombe D, Ganal M, Baker B, Bonas U, Lahaye T (2004) The tomato resistance protein $B s 4$ is a predicted non-nuclear TIR-NB-LRR protein that mediates defense responses to severely truncated derivatives of AvrBs 4 and overexpressed AvrBs3. Plant J 37:46-60

Scott J, Gardner R (2007) Breeding for resistance to fungal pathogens. In: Publ Science (ed) Genetic Improvement of Solanaceous Crops. Enfield, NH, pp 421-456

Shirasawa K, Isobe S, Hirakawa H, Asamizu E, Fukuoka H, Just D, Rothan C, Sasamoto S, Fujishiro T, Kishida Y, Kohara M, Tsuruoka H, Wada T, Nakamura Y, Sato S, Tabata S (2010) SNP discovery and linkage map construction in cultivated tomato. DNA Res 17:381-391

Sim SC, Robbins MD, Chilcott C, Zhu T, Francis DM (2009) Oligonucleotide array discovery of polymorphisms in cultivated tomato (Solanum lycopersicum L.) reveals patterns of SNP variation associated with breeding. BMC Genomics 10:466-476
Simons G, Groenendijk J, Wijbrand J, Reijans M, Groenen J, Diergaarde P, Van der Lee T, Bleeker M, Onstenk J, Both M, Haring M, Mes J, Cornelissen B, Zabeau M, Vos P (1998) Dissection of the Fusarium I2 gene cluster in tomato reveals six homologs and one active gene copy. Plant Cell 10:1055-1068

Spooner D, Peralta I, Knapp S (2005) Comparison of AFLPs with other markers for phylogenetic inference in wild tomatoes Solanum L. section Lycopersicon (Mill.) Wettst. Taxon 54:43-61

St Clair DA (2010) Quantitative disease resistance and quantitative resistance Loci in breeding. Annu Rev Phytopathol 48:247-268

Tai TH, Dahlbeck D, Clark ET, Gajiwala P, Pasion R, Whalen MC, Stall RE, Staskawicz BJ (1999) Expression of the Bs2 pepper gene confers resistance to bacterial spot disease in tomato. Proc Natl Acad Sci USA 96:14153-14158

Takken FL, Tameling WI (2009) To nibble at plant resistance proteins. Science 324:744-746

Tang X, Xie M, Kim YJ, Zhou J, Klessig DF, Martin GB (1999) Overexpression of Pto activates defense responses and confers broad resistance. Plant Cell 11:15-30

Tanksley S, McCouch S (1997) Seed banks and molecular maps: unlocking genetic potential from the wild. Science 277:1063-1066

Tewhey R, Warner JB, Nakano M, Libby B, Medkova M, David PH, Kotsopoulos SK, Samuels ML, Hutchison JB, Larson JW, Topol EJ, Weiner MP, OH JO, Link DR, Frazer KA (2009) Microdroplet-based PCR enrichment for large-scale targeted sequencing. Nat Biotechnol 27:1025-1031

Tian F, Bradbury PJ, Brown PJ, Hung H, Sun Q, Flint-Garcia S, Rocheford TR, McMullen MD, Holland JB, Buckler ES (2011) Genome-wide association study of leaf architecture in the maize nested association mapping population. Nature Genet 43(2): $159-162$

Tripodi P, Di Dato F, Maurer S, Seekh SMB, Van Haaren M, Frusciante L, Mahammad A, Tanksley S, Zamir D, Gebhardt C, Grandillo S (2010) A genetic platform of tomato multi-species introgression lines: present and future. In: The 7th Solanaceae Conference, Dundee, p 176

Uehara T, Sugiyama S, Masuta C (2007) Comparative serial analysis of gene expression of transcript profiles of tomato roots infected with cyst nematode. Plant Mol Biol 63:185-194

Ultzen T, Gielen J, Venema F, Westerbroek A, de Haan P, Tan M-L, Schram A, van Grinsven M, Goldbach R (1995) Resistance to tomato spotted wilt virus in transgenic tomato hybrids. Euphytica 85:159-168

van Esse HP, Fradin EF, de Groot PJ, de Wit PJ, Thomma BP (2009) Tomato transcriptional responses to a foliar and a vascular fungal pathogen are distinct. Mol Plant Microbe In 22:245-258

van Ooijen G, van den Burg HA, Cornelissen BJ, Takken FL (2007) Structure and function of resistance proteins in solanaceous plants. Annu Rev Phytopathol 45:43-72

Walz A, Zingen-Sell I, Loeffler M, Sauer M (2008) Expression of an oxalate oxidase gene in tomato and severity of disease caused by Botrytis cinerea and Sclerotinia sclerotiorum. Plant Pathol $57: 453-458$

Wang M, Allefs S, van den Berg R, Vleeshouwers V, van der Vossen E, Vosman B (2008) Allele mining in Solanum: conserved homologues of Rpi-blb1 are identified in Solanum stoloniferum. Theor Appl Genet 116:933-943

Weckwerth W (2011) The key role of metabolomics science in combination with next-generation genome sequencing. Anal Bioanal Chem 400:1967-1978

Whitham S, McCormick S, Baker B (1996) The $N$ gene of tobacco confers resistance to tobacco mosaic virus in transgenic tomato. P Natl Acad Sci USA 93:8776-8781

Yano K, Watanabe M, Yamamoto N, Tsugane T (2006) MiBASE: a database of a miniature tomato cultivar micro-tom. Plant Biotechnol 23:195-198 
Zhai J, Jeong DH, De Paoli E, Park S, Rosen BD, Li Y, Gonzalez AJ, Yan Z, Kitto SL, Grusak MA, Jackson SA, Stacey G, Cook DR, Green PJ, Sherrier DJ, Meyers BC (2011) MicroRNAs as master regulators of the plant NB-LRR defense gene family via the production of phased, trans-acting siRNAs. Gene Dev 25:2540-2553

Zhou J, Loh YT, Bressan RA, Martin GB (1995) The tomato gene Ptil encodes a serine/threonine kinase that is phosphorylated by Pto and is involved in the hypersensitive response. Cell 83:925-935
Zhou M, Sun J, Wang Q, Song L, Zhao G, Wang H, Yang H, Li X (2011) Genome-wide analysis of clustering patterns and flanking characteristics for plant microRNA genes. FEBS J 278(6): 929-940

Zuriaga E, Blanca J, Nuez F (2009) Classification and phylogenetic relationships in Solanum section Lycopersicon based on AFLP and two nuclear gene sequences. Genet Resour Crop Ev $56: 663-678$ 